\title{
Interaction of Styrylpyridinium Compound with Pathogenic Candida albicans Yeasts and Human Embryonic Kidney HEK-293 Cells
}

\author{
Simona Vaitkienè ${ }^{1, *}$, Laura Bekere ${ }^{2}$, Gunars Duburs ${ }^{2}$ (D) and Rimantas Daugelavičius ${ }^{1}$ (D) \\ 1 Department of Biochemistry, Faculty of Natural Sciences, Vytautas Magnus University, \\ Kaunas LT-44404, Lithuania; rimantas.daugelavicius@vdu.lt \\ 2 Latvian Institute of Organic Synthesis, Riga LV-1006, Latvia; laura.bekere.8@gmail.com (L.B.); \\ gduburs@osi.lv (G.D.) \\ * Correspondence: simona.vaitkiene@vdu.lt
}

Citation: Vaitkienè, S.; Bekere, L.; Duburs, G.; Daugelavičius, R. Interaction of Styrylpyridinium Compound with Pathogenic Candida albicans Yeasts and Human Embryonic Kidney HEK-293 Cells. Microorganisms 2021, 9, 48. https://dx.doi.org/10.3390/ microorganisms 9010048

Received: 10 November 2020 Accepted: 22 December 2020 Published: 27 December 2020

Publisher's Note: MDPI stays neutral with regard to jurisdictional claims in published maps and institutional affiliations.

Copyright: () 2020 by the authors. Licensee MDPI, Basel, Switzerland. This article is an open access article distributed under the terms and conditions of the Creative Commons Attribution (CC BY) license (https: / / creativecommons.org/ licenses/by/4.0/).

\begin{abstract}
Candida albicans-caused local and systemic diseases are a serious health issue worldwide, leading to high mycosis-associated morbidity and mortality. Efficient combinations of novel compounds with commonly used antifungals could be an important tool for fighting infections. The aim of this study was to evaluate the interaction of synthesized 4-(4-cyanostyryl)-1-dodecylpyridin-1-ium $\left(\mathrm{CSDP}^{+}\right)$bromide alone or in combination with fluconazole with yeast and mammalian cells. We investigated cytotoxicity of the tested agents to mammalian HEK-293 cells and the influence of CSDP ${ }^{+}$ on the ability of C. albicans wt and a clinical isolate to adhere to HEK-293. Accumulation of lipophilic cation ethidium $\left(\mathrm{Et}^{+}\right)$was used to monitor the activity of efflux pumps in HEK-293 cells. The effect of $\mathrm{CSDP}^{+}$on the expression of the main efflux transporter genes and transcription factors in C. albicans cells as well as HEK-293 efflux pump gene $A B C B 1$ was determined. The study showed that CSDP ${ }^{+}$ alone and in combination with fluconazole was nontoxic to HEK-293 cells and was able to reduce C. albicans adhesion. The treatment of $C$. albicans cells with $\mathrm{CSDP}^{+}$in combination with fluconazole resulted in a considerable overexpression of the MDR1 and MRR1 genes. The findings suggest that these genes could be associated with efflux-related resistance to fluconazole. Measurements of $\mathrm{Et}^{+}$ fluorescence and analysis of $A B C B 1$ gene expression demonstrated that mammalian cells were not sensitive to concentrations of $\mathrm{CSDP}^{+}$affecting C. albicans.
\end{abstract}

Keywords: styrylpyridinium; Candida albicans; HEK-293; adhesion; cytotoxicity; gene expression; multidrug resistance; efflux pumps

\section{Introduction}

Resistance to antifungal treatment, especially to the drugs of the azole class, is a serious problem in the case of fungal pathogen Candida albicans. Various molecular mechanisms of resistance in susceptible and resistant clinical isolates have been discussed [1,2]. An important factor involved in C. albicans pathogenesis is the ability of yeasts to adhere to host cells and to change the cell shape from ellipsoidal to filamentous [3-5]. C. albicans adhesion to host tissues contributes to biofilm formation and increases virulence. However, relatively little is known about molecular mechanisms leading to C. albicans infections in human tissues and adhesion to medicinal materials.

In our previous study, we have demonstrated [6] that styrylpyridinium compounds, for a few decades known as fluorescent probes [7,8] or for their antimicrobial properties against bacteria [9], efficiently inhibited the growth of C. albicans cells. The most active styrylpyridinium compound 4-(4-cyanostyryl)-1-dodecylpyridin-1-ium (CSDP ${ }^{+}$) bromide inhibited the growth and respiration of $C$. albicans cells very effectively. In addition, a strong synergistic effect was demonstrated when $\mathrm{CSDP}^{+}$was used in combination with fluconazole. At the same time, the results of our experiments showed that in the absence 
of functioning efflux pump genes, C. albicans cells were more susceptible to CSDP ${ }^{+}$[6] These results are consistent with the data [10] that $C$. albicans resistance to antifungal drugs is associated with the reduced intracellular concentration of these compounds.

It is well known that the genes of $A B C$ transporters $C D R 1$ and $C D R 2$, encoding ATP-dependent efflux pumps, are overexpressed in resistant $C$. albicans strains, especially in those not sensitive to the drugs of the azole class. Deletion of these genes causes hypersensitivity to azoles [1,11,12]. Expression of ABC transporters Cdr1 and Cdr2 is controlled by the zinc cluster transcription factor TAC1, directly binding to drug-responsive elements in gene promoters. In general, "gain-of-function" mutations induce hyperactivity of the transcription factor TAC1, increasing the expression of CDR1 and CDR2 [13,14].

The MDR1 gene encodes a transporter of the major facilitator superfamily that uses the proton motive force for the extrusion of drugs and other noxious compounds from cells. Overexpression of this pump causes resistance, and deletion of the transporter gene results in the hypersensitivity of cells to azoles [1]. MRR1, a zinc cluster transcription factor, mediates the expression of MDR1 in response to different chemicals, and overexpression also causes the activation of "gain-of-function" mutations in the MRR1 transcription factor [15].

Resistance of mammalian tissues to lipophilic and amphiphilic compounds also involves $\mathrm{ABC}$ transporters. The best characterized MDR genes in mammalians include $A B C B 1$ (also known as MDR1 or P-glycoprotein), $A B C C 1$ (also known as MRP1), and ABCG2 (also known as $B C R P$ or $M X R$ ) [16]. However, we need more information how mammalian cells interact with antifungals.

Due to the lack of information about the mechanisms of action of styrylpyridinium compounds, we designed this study to evaluate the effects of $\mathrm{CSDP}^{+}$on the ability of $C$. albicans to adhere to human kidney embryonic cells HEK-293 and to affect the expression levels of efflux pump genes in C. albicans and HEK-293 cells. The study revealed that CSDP ${ }^{+}$ alone and in combination with fluconazole reduced C. albicans adhesion and resulted in a considerable overexpression of the MDR1 and MRR1 genes.

\section{Materials and Methods}

\subsection{Chemistry}

Synthesis of $\mathrm{CSDP}^{+}$from 4-methyl-1-dodecyl-4-methylpyridinium-1 bromide and 4-cyanobenzaldehyde was described in our previous study [6].

\subsection{Strains and Cell Lines}

C. albicans strain ATCC10231 (wild type, wt) and clinical isolate SV1 were studied. Yeast cultures were grown in YPD media (1\% yeast extract, $2 \%$ peptone, $2 \%$ glucose) at $37^{\circ} \mathrm{C}$ for $18 \mathrm{~h}$.

Human embryonic kidney cell line HEK-293 was used in this study. HEK-293 cells were grown in minimal essential amino acids medium (MEM), supplemented with fetal bovine serum $(10 \%$ v/v; GIBCO; Life Technologies, Grovemont Cir, Gaithersburg, MD, USA), streptomycin/penicillin ( $2 \% v / v$; GIBCO; Life Technologies, Grovemont Cir, Gaithersburg, MD, USA), and Amphotericin B (1\% v/v; GIBCO; Life Technologies, Grovemont Cir, Gaithersburg, MD, USA) in 75- $\mathrm{cm}^{2}$ Falcon culture flasks under standard conditions $\left(5 \% \mathrm{CO}_{2}\right.$ in air at $\left.37^{\circ} \mathrm{C}\right)$.

\subsection{Adhesion Assay}

The adhesion assay was carried out as described elsewhere [17], with some modifications. HEK-293 cells were grown in $75-\mathrm{cm}^{2}$ Falcon culture flasks in MEM, and after reaching confluence, the adhesion of $C$. albicans was assessed. The amount of $1 \times 10^{5}$ cells/well was used to inoculate MEM-containing 24-well tissue culture plates and incubated at $37^{\circ} \mathrm{C}$ for $24 \mathrm{~h}$ to reach a confluent monolayer. Before the experiments, yeast cells were grown in yeast extract-peptone-dextrose (YPD) medium for $18 \mathrm{~h}$, pelleted at $3000 \times \mathrm{g}$ for $10 \mathrm{~min}$, and resuspended in MEM medium without antimicrobials. HEK-293 cells, cultured for $24 \mathrm{~h}$, 
were washed three times with phosphate-buffered solution (PBS, $\mathrm{pH} 7.5)$. Yeast suspension $\left(100 \mu \mathrm{L}, 1 \times 10^{6}\right.$ cells) was inoculated into plate wells containing antimicrobials. $\mathrm{CSDP}^{+}$ $(0.25-16 \mu \mathrm{g} / \mathrm{mL})$, fluconazole $(0.0625-0.5 \mu \mathrm{g} / \mathrm{mL})$, or combination of $0.25-\mu \mathrm{g} / \mathrm{mL} \mathrm{CSDP}^{+}$ and $0.0625-\mu \mathrm{g} / \mathrm{mL}$ fluconazole were used for the adhesion assay.

C. albicans cells were maintained in contact with HEK-293 for $2 \mathrm{~h}$. After this procedure, the wells were washed three times with PBS to remove unattached yeasts, and HEK293 cells were detached using 1-mL trypsin-EDTA (Gibco) diluted in PBS, incubating at $37^{\circ} \mathrm{C}$ for $5 \mathrm{~min}$. Aliquots of $20 \mu \mathrm{L}$ were taken, serially diluted, inoculated onto SDA plates, and incubated for $24 \mathrm{~h}$. Finally, the number of yeasts adhered to HEK-293 cells was assessed by counting the colony-forming units (CFU). In the control group, yeast suspensions were not treated with any compounds.

\subsection{Evaluation of Cytotoxicity}

To evaluate cytotoxicity, HEK-293 cells were grown in MEM as described in the adhesion assay. After reaching sufficient confluence, the cells were passaged by trypsinization. Effects of the studied compounds on HEK-293 cells were examined using a 2,3-bis [2-methoxy-4-nitro-5-sulfophenyl]-2H-tetrazolium-5-carboxanilide (XTT) viability assay. This assay is based on the ability of metabolically active (live) cells to reduce XTT tetrazolium salt, leading to the formation of orange-colored formazan compounds.

HEK-293 cells were grown in 96-well plates, starting from $1 \times 10^{4}$ cells per well. After 24-h incubation, the culture medium was carefully aspirated (avoiding damage of the attached cells), and wells were gently washed with PBS two times. Solutions of $\mathrm{CSDP}^{+}$, fluconazole, or combination of both agents were added to the plate wells and incubated at $37^{\circ} \mathrm{C}$ for $24 \mathrm{~h}$. After incubation, the medium was removed from wells, and $100 \mu \mathrm{L}$ of fresh MEM and $50 \mu \mathrm{L}$ of XTT solution were added to each well. The plates were covered to avoid direct light and incubated at $37{ }^{\circ} \mathrm{C}$ for $2 \mathrm{~h}$ to induce formation of the formazan dye. After incubation, the plates were gently shaken, and absorbance was spectrophotometrically registered at $492 \mathrm{~nm}$ using a TECAN GENios Pro ${ }^{\mathrm{TM}}$ plate reader.

Viability was calculated according to the equation:

Viability of cells $(\%)=\frac{\text { absorbance of cells treated with compounds }}{\text { absorbance of untreated cells }} \times 100 \%$

\subsection{Fluorescence Measurement}

Accumulation of ethidium $\left(\mathrm{Et}^{+}\right)$, well known as an efflux pump substrate, was used to monitor the efflux activity in HEK-293 cells. Stock solution of ethidium bromide (EtBr; Sigma Aldrich, USA) was added to cell suspensions to the final concentration of $0.5 \mu \mathrm{M}$. The samples were mixed, and volumes of $120 \mu \mathrm{L}$ were transferred into 96-well flat-bottom black plates $\left(60,000\right.$ cells per well) within $2 \mathrm{~min}$. At the same time, $\mathrm{CSDP}^{+}$and fluconazole, as well as their combination, were added to the wells. Fluorescence was monitored by using a TECAN GENios Pro ${ }^{\mathrm{TM}}$ (Männedorf, Switzerland) reader at an excitation wavelength of $535 \mathrm{~nm}$ and emission wavelength of $612 \mathrm{~nm}$, thermostating the plate at $37^{\circ} \mathrm{C}$. After $30 \mathrm{~min}$, detergent digitonin was added to all wells to the final concentration of $0.1 \mathrm{mg} / \mathrm{mL}$. Measurements were continued for 10 min to obtain the maximum binding of $\mathrm{Et}^{+}$to DNA, leading to the maximal $\mathrm{Et}^{+}$fluorescence. In controls, the cells were not treated with any compound, or digitonin was added to the cell suspensions before EtBr.

Accumulation of $\mathrm{Et}+(\%)=\frac{\text { fluorescence of measurement point every } 5 \mathrm{~min}}{\text { fluorescence at the last point of the measurement }} \times 100 \%$

\subsection{Analysis of Gene Expression}

The expression of C. albicans efflux pump CDR1, CDR2, and MDR1, and transcription factor MRR1 and TAC1 genes as well as the expression of HEK-293 efflux pump gene $A B C B 1$ were evaluated after exposure to $\mathrm{CSDP}^{+}$, fluconazole, and combination of both compounds.

Yeast cultures were grown for $18 \mathrm{~h}$ in the YPD medium under different conditions: in the presence of the tested compounds or in the absence of any compounds. Pellets of 
overnight cultures were collected by centrifugation at $4{ }^{\circ} \mathrm{C}$ for $10 \mathrm{~min}$ at $3000 \times g$ (Heraeus Megafuge 16R, ThermoFisher Scientific, Osterode am Harz, Germany). HEK-293 cells, starting with 60,000 cells/well, were grown in 6-well plates under the same conditions as yeast cells: in the presence of $\mathrm{CSDP}^{+}$, fluconazole, and their combination or in the absence of any compounds.

Total RNA from SV1 and wt cells was extracted using a Trizol Plus RNA kit (Invitrogen, Carlsbad, CA, USA) with ZR BashingBead Lysis Tubes (Zymo Research, Irvine, CA, USA). For HEK-293 RNA isolation, the same kit, but without glass beads, was used following the instructions. cDNA synthesis was performed using a High Capacity cDNA Reverse Transcription Kit (Applied Biosystems, Carlsbad, CA, USA), according to the manufacturer's instructions. RT-PCR was performed using StepOne ${ }^{\mathrm{TM}}$ and StepOnePlus ${ }^{\mathrm{TM}}$ Systems (Applied Biosystems, Foster city, CA, USA) in $20-\mu \mathrm{L}$ reaction volume containing the Power SYBR Green RT-PCR Mix (ThermoFisher Scientific, Osterode am Harz, Germany), cDNA template, forward and reverse primers (Table 1, ThermoFisher Scientific, Osterode am Harz, Germany). RT-PCR conditions for CDR1, CDR2, MDR1, MRR1, and TAC1 genes were as follows: $95^{\circ} \mathrm{C}$ for $5 \mathrm{~min}$, followed by 40 cycles at $95^{\circ} \mathrm{C}$ for $15 \mathrm{~s}$, and $60^{\circ} \mathrm{C}$ for $30 \mathrm{~s}$. RT-PCR conditions for $A B C B 1$ were as follows: $95^{\circ} \mathrm{C}$ for $5 \mathrm{~min}$, followed by 40 cycles at $95{ }^{\circ} \mathrm{C}$ for $15 \mathrm{~s}$, and $58{ }^{\circ} \mathrm{C}$ for $30 \mathrm{~s}$. To determine the expression of genes of interest, the differences $(\Delta)$ between threshold cycles $(\mathrm{Ct})$ were measured. Data were presented as a fold change in gene expression normalized to the $18 S$ gene (for yeast) and GAPDH gene (for HEK-293) as a control.

Table 1. Primers used in the study.

\begin{tabular}{|c|c|}
\hline \multirow{2}{*}{ CDR1 } & 5'-GTACTATCCATCAACCATCAGCACTT-3' (forward) \\
\hline & 5'-GCCGTTCTTCCACCTTTTTGTA-3' (reverse) \\
\hline \multirow{2}{*}{ CDR2 } & 5'-TGCTGAACCGACAGACTCAGTT-3' (forward) \\
\hline & 5'-AAGAGATTGCCAATTGTCCCATA-3' (reverse) \\
\hline \multirow{2}{*}{ MDR1 } & 5'-TCAGTCCGATGTCAGAAAATGC-3' (forward) \\
\hline & 5'-GCAGTGGGAATTTGTAGTATGACAA-3' (reverse) \\
\hline \multirow{2}{*}{ TAC1 } & 5'-GAAATTGTTAATGACGGTTCTACCTTC-3' (forward) \\
\hline & 5'-TATTCATATACCCAACCGGAAATTGG-3' (reverse) \\
\hline \multirow{2}{*}{ MRR1 } & 5'-AACGCTGGTTATGGGTGA-3' (forward) \\
\hline & 5'-TTTGCTGTTGGGCTTCTT-3' (reverse) \\
\hline \multirow{2}{*}{$18 S$} & 5'-GGATTTACTGAAGACTAACTACTG-3' (forward) \\
\hline & 5'-GAACAACAACCGATCCCTAGT-3' (reverse) \\
\hline \multirow{2}{*}{ GAPDH } & 5'-GTCTCCTCTGACTTCAACAGCG-3' (forward) \\
\hline & 5'-ACCACCCTGTTGCTGTAGCCAA-3' (reverse) \\
\hline \multirow{2}{*}{$A B C B 1$} & 5'-GTCCCAGGAGCCCATCCT-3' (forward) \\
\hline & 5'-CCCGGCTGTTGTCTCCATA-3' (reverse) \\
\hline
\end{tabular}

\subsection{Statistical Analysis}

Statistical analysis was performed using the GraphPad Prism 8 software (ver. 8.01, 2018; GraphPad Software Inc., San Diego, CA, USA). All the experiments were performed in three biological replicates with three technical repetitions. Results are expressed as means \pm standard deviation (SD).

\section{Results and Discussion}

Our previous studies demonstrated that $\mathrm{CSDP}^{+}$acted fungicidally against $C$. albicans wt, $c d r 1 \Delta, c d r 2 \Delta$, and $c d r 1 \Delta c d r 2 \Delta$ strains, and the higher concentration was required to in- 
hibit the growth of SV1 strain cells. $\mathrm{MIC}_{50}$ of $\mathrm{CSDP}^{+}$for wt cells was $2.8 \mu \mathrm{g} / \mathrm{mL}$, and $\mathrm{MIC}_{90}$ was $8 \mu \mathrm{g} / \mathrm{mL}$. The SV1 strain demonstrated increased resistance to this compound and $16 \mu \mathrm{g} / \mathrm{mL}$ was required to inhibit the growth of these cells $90 \%$. $\mathrm{MIC}_{50}$ and $\mathrm{MIC}_{90}$ of fluconazole for both yeast strains were $0.15 \mu \mathrm{g} / \mathrm{mL}$ and $0.5 \mu \mathrm{g} / \mathrm{mL}$, respectively. Combination of these two compounds showed a relevant synergism with $\Sigma$ FIC of 0.19 for SV1 strain cells and 0.38 for wt ones. Treatment with $\mathrm{MIC}_{90}$ of $\mathrm{CSDP}^{+}$, needed to inhibit the growth of C. albicans SV1 cells by $90 \%$, resulted in a $30 \%$ decrease in the viability of CHO-K1 cells, but fungicidal concentration $(1 \mu \mathrm{g} / \mathrm{mL})$ of fluconazole in combination with $0.25 \mu \mathrm{g} / \mathrm{mL}$ of $\mathrm{CSDP}^{+}$reduced viability of $\mathrm{CHO}-\mathrm{K} 1$ cells only by $10 \%$. The results suggested that $\mathrm{CSDP}^{+}$ could be a promising agent for combined antifungal treatment [6].

\subsection{Adhesion of C. albicans to HEK-293 Cells}

The binding of $C$. albicans to the surface of host cells is an important step in the process of infection, and its ability to adhere is a critical feature in the processes of colonization and persistence in tissues $[17,18]$. Therefore, one of the promising approaches to reduce yeast-caused infections is the development of adhesion-preventing agents. We aimed to find out how $\mathrm{CSDP}^{+}$, fluconazole, and their combination impact the adhesion of $\mathrm{C}$. albicans wt and SV1 strain yeasts to human embryonic kidney cell line HEK-293 cells.

The results showed that in the presence of $0.25 \mu \mathrm{g} / \mathrm{mL}$ of $\mathrm{CSDP}^{+}$, the adhesion of C. albicans to the surface of HEK-293 cells decreased by $34 \%$ and $32 \%$ for wt and SV1 strain cells, respectively (Figure 1). After the increase of $\mathrm{CSDP}^{+}$concentration to $16 \mu \mathrm{g} / \mathrm{mL}$, the adherence of wt and SV1 strain yeasts to HEK-293 cells decreased by 54\% and 36\%, respectively. The effect of fluconazole on the adhesion of C. albicans to HEK-293 cells was negligible. However, a $60 \%$ and $40 \%$ decrease in the adherence of C. albicans wt and SV1 strain cells, respectively, was documented when the combination of low concentrations of fluconazole and $\mathrm{CSDP}^{+}$was applied (Figure 1).

Summarizing our results, we can conclude that $\mathrm{CSDP}^{+}$alone and in combination with fluconazole markedly reduced the ability of C. albicans to adhere to HEK-293 cells.

\subsection{Cytotoxicity to HEK-293 Cells}

In the following experiments, we verified the effects of $\mathrm{CSDP}^{+}$and fluconazole on the viability of HEK-293 cells. Viability of HEK-293 cells gradually diminished to $74 \%$ when the concentration of $\mathrm{CSDP}^{+}$increased from 0.25 to $16 \mu \mathrm{g} / \mathrm{mL}$. However, at the concentration of $64 \mu \mathrm{g} / \mathrm{mL}$, this compound reduced the viability of HEK-293 cells to $15 \%$ (Figure 2). In the presence of fluconazole (up to $1 \mu \mathrm{g} / \mathrm{mL}$ ) or combination of these compounds, the survival rate of HEK-293 cells ranged between $90 \%$ and 100\% (Figure 2).

Summarizing, $\mathrm{CSDP}^{+}$at concentrations up to $16 \mu \mathrm{g} / \mathrm{mL}$ as well as fluconazole or combination of these two drugs showed no significant effect on the viability of HEK-293 cells. The results of these experiments support our previous findings with hamster cells [6] demonstrating that $\mathrm{CSDP}^{+}$has the weakest effect on the viability of $\mathrm{CHO}-\mathrm{K} 1$ cells among various styrylpyridinium compounds.

\subsection{Effect of CSDP ${ }^{+}$and Fluconazole on Et $t^{+}$Fluorescence in HEK-293 Cell Suspensions}

A fluorescent probe EtBr is widely used as a substrate for studies on efflux pump activities in bacterial and eukaryotic cells $[19,20]$. In aqueous solutions, the fluorescence of $\mathrm{Et}^{+}$is very weak, but it considerably increases when this indicator gets into cells, mainly due to the intercalation into DNA or dsRNA [21]. Efflux pumps remove $\mathrm{Et}^{+}$from the cells, and the intensity of fluorescence correlates well with the activity of extrusion [22,23]. Here we investigated the effects of $\mathrm{CSDP}^{+}$and fluconazole on the efflux of $\mathrm{Et}^{+}$from HEK-293 cells. 

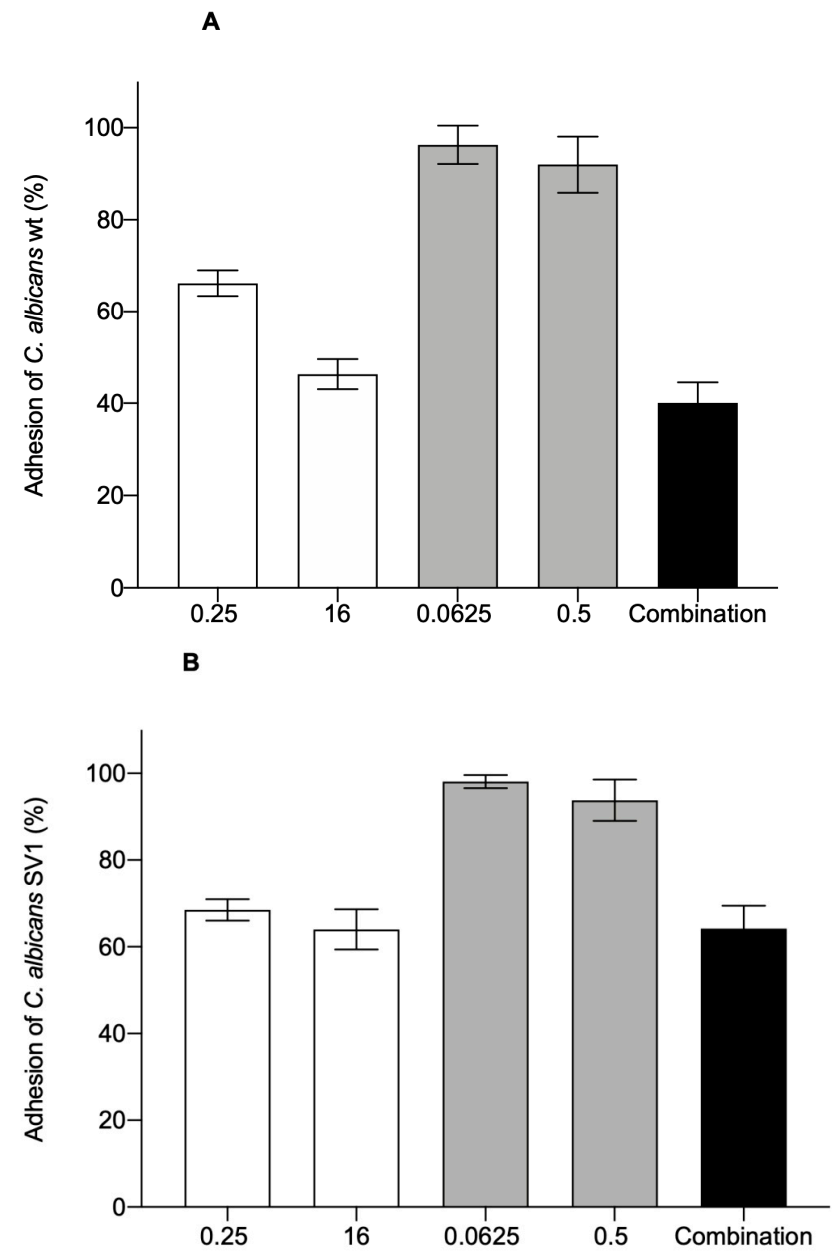

Figure 1. Adhesion of C. albicans wt (A) and SV1 (B) yeasts to the surface of HEK-293 cells. Cells were treated with different concentrations $\left(\mu \mathrm{g} / \mathrm{mL}\right.$ ) of $\mathrm{CSDP}^{+}$(white bars), fluconazole (grey bars), and their combination $\left(0.25 \mu \mathrm{g} / \mathrm{mL}\right.$ of $\mathrm{CSDP}^{+}$and $0.0625 \mu \mathrm{g} / \mathrm{mL}$ of fluconazole, black bars). Data are shown as mean \pm standard deviation (SD). In the absence of any compounds, $100 \%$ adhesion was registered.

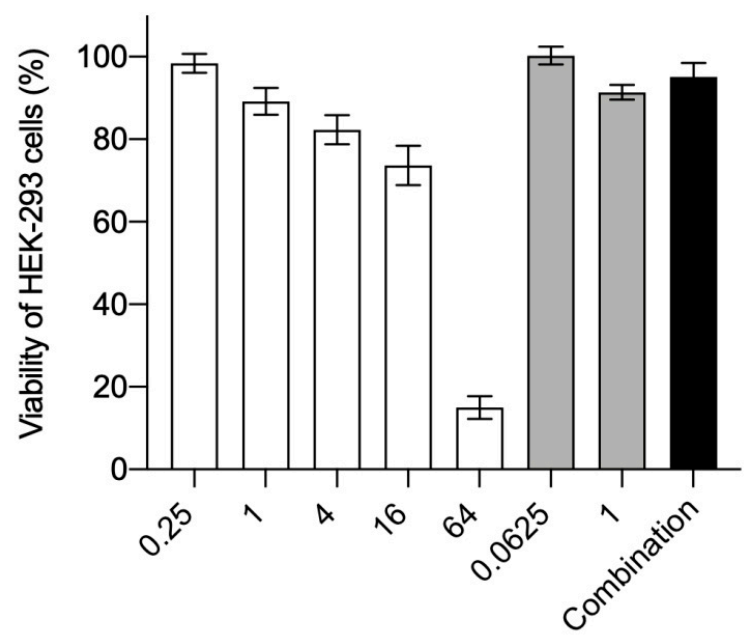

Figure 2. Effect of $\mathrm{CSDP}^{+}$and fluconazole on the viability of HEK-293 cells. The cells were treated with CSDP+ (white bars), fluconazole (grey bars), and their combination $(0.0625 \mu \mathrm{g} / \mathrm{mL}$ of fluconazole and $0.25 \mu \mathrm{g} / \mathrm{mL}$ of $\mathrm{CSDP}^{+}$, black bar). Data are shown as mean \pm standard deviation (SD). The level of $100 \%$ corresponds to the viability of HEK-293 cells not treated with any compound. 
At a concentration of $0.25 \mu \mathrm{g} / \mathrm{mL}, \mathrm{CSDP}^{+}$alone or in the presence of fluconazole, the intensity of $\mathrm{Et}^{+}$fluorescence was close to the level of control cells, incubated without any additions (Figure 3). After the exposure of HEK-293 cells to $16 \mu \mathrm{g} / \mathrm{mL}$ of CSDP ${ }^{+}$, the intensity of fluorescence was $10 \%-20 \%$ higher, and at the concentrations of $64-128 \mu \mathrm{g} / \mathrm{mL}$, $\mathrm{CSDP}^{+}$was able to increase $\mathrm{Et}^{+}$fluorescence close to the level of control cells in the presence of non-ionic detergent digitonin (Figure 3). Digitonin is a detergent permeabilizing the plasma membrane. The maximum fluorescence of $\mathrm{Et}^{+}$was achieved after digitonin addition, indicating the maximum binding of this lipophilic ion to DNA [24].

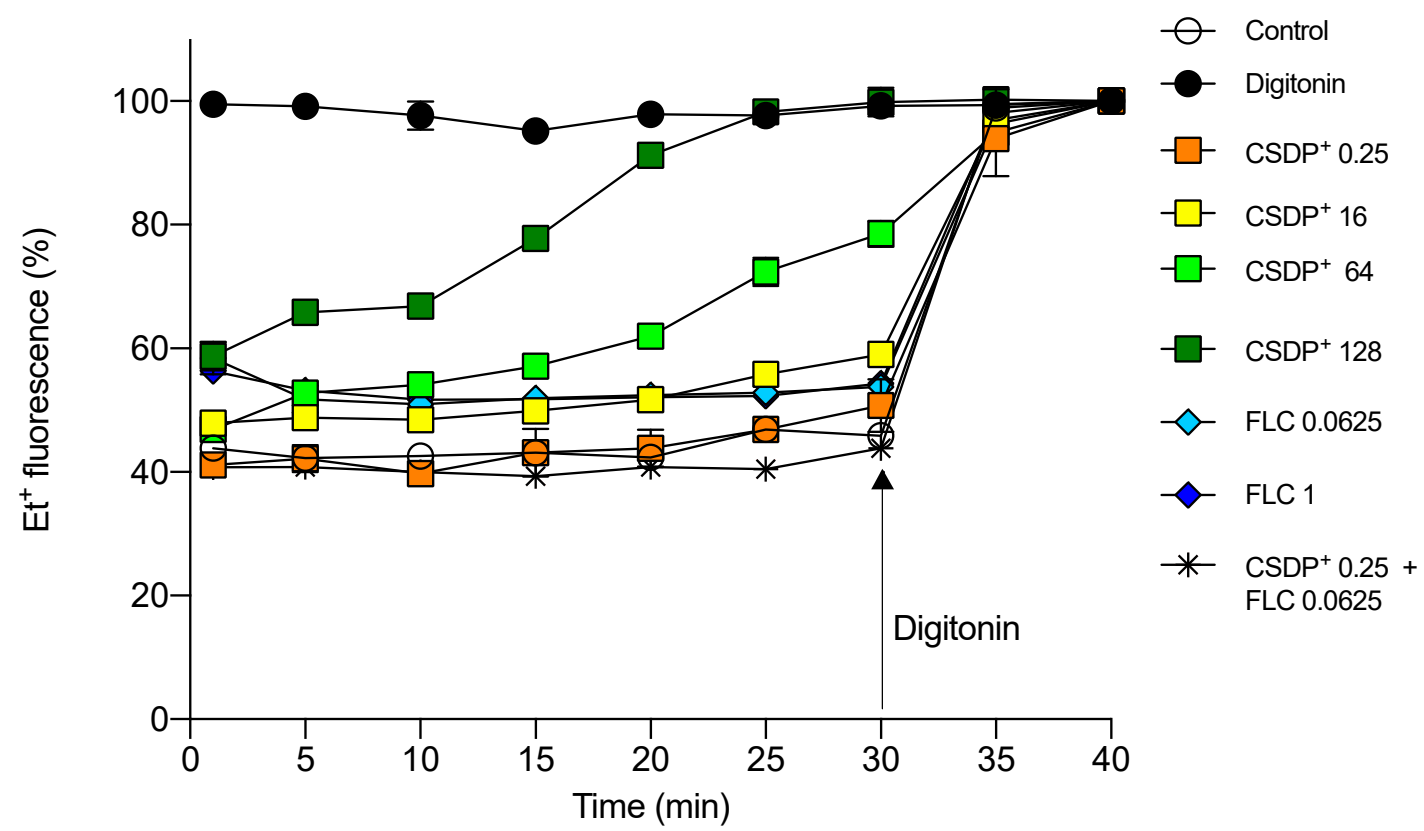

Figure 3. $\mathrm{Et}^{+}$fluorescence in HEK-293 cell suspensions. Fluorescence of $\mathrm{Et}^{+}$was registered in the presence of different concentrations $(\mu \mathrm{g} / \mathrm{mL})$ of $\mathrm{CSDP}^{+}$and fluconazole (FLC). In control measurements, the cells were not treated with any compound or the medium contained $0.1 \mathrm{mg} / \mathrm{mL}$ of a lysing agent digitonin. Data are shown as mean \pm standard deviation (SD).

The obtained results suggest that $\mathrm{CSDP}^{+}$at low concentrations $(<16 \mu \mathrm{M})$ does not damage HEK-293 cells, and efflux pumps efficiently prevent $\mathrm{Et}^{+}$entry. However, at the concentrations of $\mathrm{CSDP}^{+}$of more than $64 \mu \mathrm{g} / \mathrm{mL}, \mathrm{Et}^{+}$gets easier into the cells because of the increased permeability of the plasma membrane or the inhibition of efflux.

\subsection{Expression of efflux pump genes in C. albicans}

Our previous study [6] demonstrated that the expression of CDR1, CDR2, and especially MDR1 genes in SV1 cells was significantly higher as compared with wt cells. It is known that the overexpression of MDR1 is a factor promoting the resistance of pathogenic C. albicans to fluconazole and other toxic compounds [15]. In clinical C. albicans isolates, MDR1 overexpression is usually accompanied by the upregulation of other genes. For example, $C$. albicans strains that had become fluconazole-resistant due to constitutive MDR1 upregulation contained also mutations in MRR1 gene, which controls MDR1 expression [25].

The results of our experiments indicated that wt cells treated with $2 \mu \mathrm{g} / \mathrm{mL}$ of CSDP ${ }^{+}$ demonstrated a mild increase in the expression of CDR1 and CDR2 genes, while no significant changes in the expression of TAC1 were documented compared with untreated cells (Figure 4A). The slight activation of the MDR1 gene was also observed, but the greatest increase (44.36 \pm 3.12 -fold) was documented for MRR1 expression (Figure 4A). 


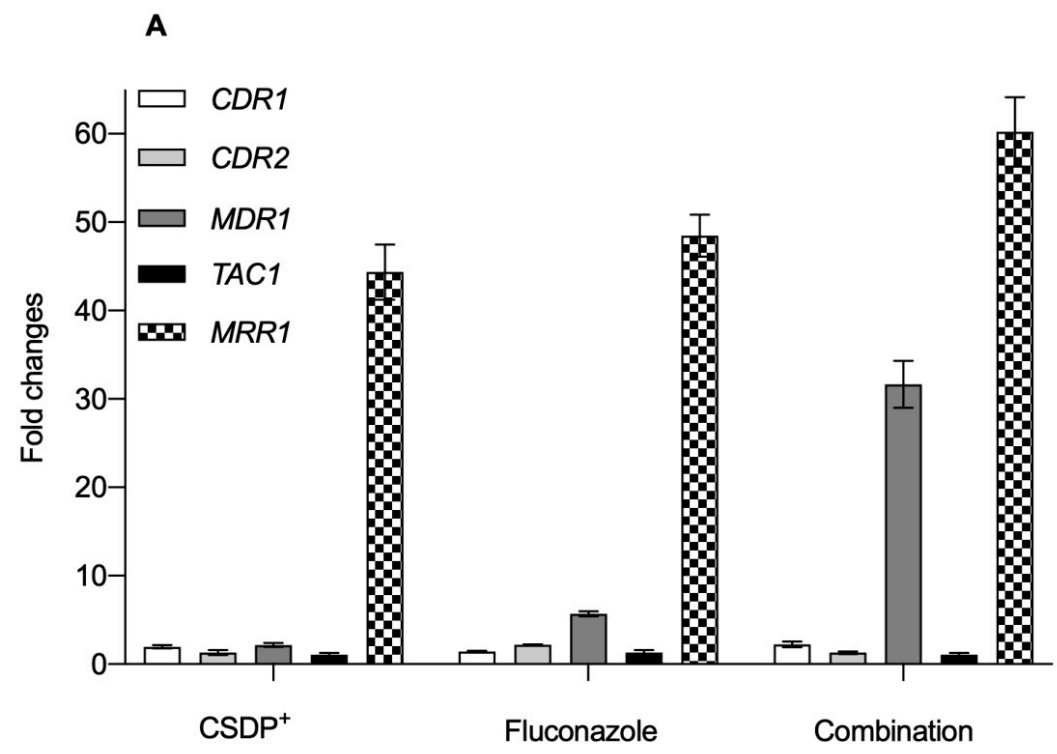

B

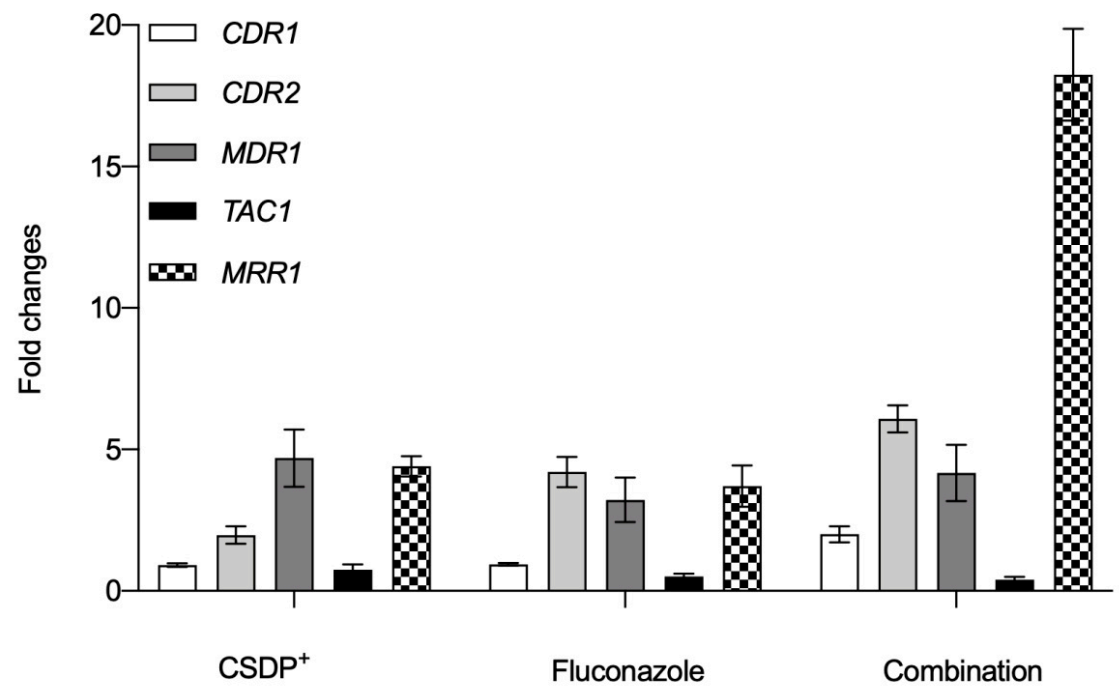

Figure 4. Gene expression in C. albicans wt (A) and SV1 (B) strain cells. The cells were treated with $2 \mu \mathrm{g} / \mathrm{mL}$ of $\mathrm{CSDP}^{+}, 0.125 \mu \mathrm{g} / \mathrm{mL}$ of fluconazole or combination of both agents $(0.25 \mu \mathrm{g} / \mathrm{mL}$ of $\mathrm{CSDP}^{+}$and $0.0625 \mu \mathrm{g} / \mathrm{mL}$ of fluconazole). Data are shown as a mean fold change in gene expression relative to control nontreated C. albicans wt or SV1 cells.

Cell treatment with $0.125 \mu \mathrm{g} / \mathrm{mL}$ of fluconazole caused a significant increase in the expression of CDR1, CDR2, and TAC1 genes as compared with control cells (Figure 4A). As in the case of pretreatment with $\mathrm{CSDP}^{+}$, an elevated expression of $M D R 1$ and overexpression of MRR1 were observed in fluconazole-treated wt cells (Figure 4A). Exposure of wt cells to $0.0625 \mu \mathrm{g} / \mathrm{mL}$ of fluconazole and $0.25 \mu \mathrm{g} / \mathrm{mL}$ of $\mathrm{CSDP}^{+}$also slightly increased the expression of CDR1 and CDR2 (Figure 4A). Combination of these compounds had no significant effect on TAC1 expression (Figure 4), but markedly increased MDR1 and MRR1 expression (31.65 \pm 2.64 and $60.22 \pm 3.93$-fold, respectively; Figure 4A).

Further, we evaluated the effect of $\mathrm{CSDP}^{+}$and fluconazole on the expression of CDR1, CDR2, MDR1, TAC1, and MRR1 genes in C. albicans cells of SV1 strain. In this case after cell treatment with $2 \mu \mathrm{g} / \mathrm{mL}$ of $\mathrm{CSDP}^{+}$, there were no significant changes in the expression of CDR1 and TAC1 genes (Fig. 4B). Meanwhile, the expression of CDR2 significantly increased after $\mathrm{CSDP}^{+}$treatment (Figure $4 \mathrm{~B}$ ). $\mathrm{CSDP}^{+}$also caused an elevation of MDR1 and $M R R 1$ expression (Figure 4B). The same tendency was observed in the case of fluconazole: 
expression levels of $C D R 2$ as well as MDR1 and MRR1 were increased compared with control (Figure 4B).

SV1 cells treated with the combination of both agents showed a $2.0 \pm 0.28$-fold and a $6.08 \pm 0.48$-fold increase in the expression of $C D R 1$ and $C D R 2$ genes, respectively, as compared with untreated cells (Figure 4B). A mild increase in MDR1 expression was also observed (Figure 4B). Similarly, as in the case of wt cells, the greatest overexpression, up to 20-fold, was observed for the MRR1 gene after the exposure of SV1 cells to the combination of $\mathrm{CSDP}^{+}$and fluconazole (Figure $4 \mathrm{~B}$ ).

Under normal conditions, the MDR1 gene is usually not expressed in fluconazolesusceptible isolates [26]. However, it was demonstrated that $C$. albicans isolates from abdominal fluid, susceptible to fluconazole but mildly resistant to itraconazole, had a high expression of the MDR1 gene [1,27]. Moreover, it was recorded that the deletion of $M R R 1$ from the drug-susceptible C. albicans wt strain also abolishes MDR1 expression in the presence of inducing chemicals, such as benomyl and hydrogen peroxide. This fact demonstrates that the transcription factor MRR1 mediates both: an inducible MDR1 expression in drug-susceptible strains and a constitutive MDR1 overexpression in drugresistant strains [26].

\subsection{Expression of the efflux pump ABCB1 gene in HEK-293}

Efflux pump ABCB1 protects mammalian organisms by extruding various xenobiotics and drugs from cells. Under pathological conditions, the overexpression of $A B C B 1$ in tumor cells results in multidrug resistance [28]. As determined by the measurements of $\mathrm{Et}^{+}$ fluorescence, $\mathrm{CSDP}^{+}$at low concentrations alone or in combination with fluconazole did not show any considerable effect on the efflux activity in HEK-293 cells (Figure 3). Despite this, we checked the effect of $\mathrm{CSDP}^{+}$on the expression of the $A B C B 1$ gene in HEK-293 cells. The results of experiments indicated that after the treatment of cells with $0.25 \mu \mathrm{g} / \mathrm{mL}$ of $\mathrm{CSDP}^{+}$, the expression of the $A B C B 1$ gene in HEK-293 cells was $1.99 \pm 0.15$-fold higher (Figure 5). Fluconazole at a concentration of $0.0625 \mu \mathrm{g} / \mathrm{mL}$ caused a $1.18 \pm 0.05$-fold increase, and the combination of both compounds at low concentrations resulted in a $1.11 \pm 0.08$-fold increase in the $A B C B 1$ expression (Figure 5).

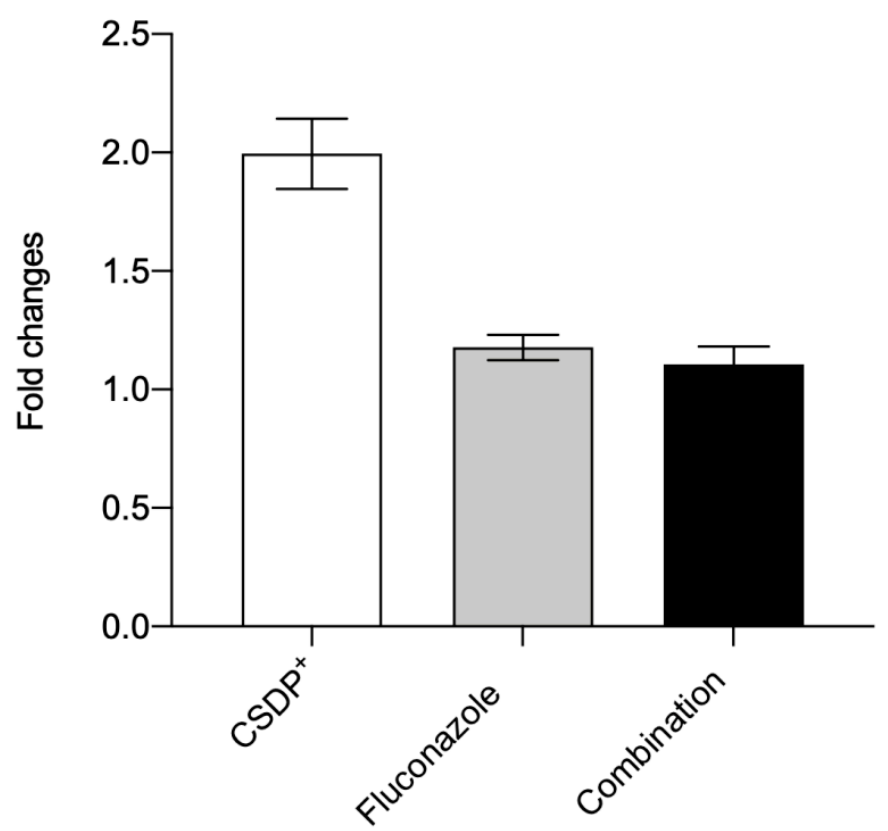

Figure 5. Expression of the $A B C B 1$ gene in HEK-293 cells. The cells were treated with CSDP ${ }^{+}$ $(0.25 \mu \mathrm{g} / \mathrm{mL})$, fluconazole $(0.0625 \mu \mathrm{g} / \mathrm{mL})$, or a combination of both agents $\left(0.25 \mu \mathrm{g} / \mathrm{mL}\right.$ of CSDP ${ }^{+}$ and $0.0625 \mu \mathrm{g} / \mathrm{mL}$ of fluconazole). Data are shown as a mean fold change in the gene expression relative to control nontreated HEK-293 cells. 
In summary, the expression of the efflux pump gene $A B C B 1$ is only weakly increased after the exposure of HEK-293 cells to the tested compounds. Only a slight increase in $A B C B 1$ expression and low fluorescence of $\mathrm{Et}^{+}$ions registered during the efflux measurements indicate very limited damage of the plasma membrane caused by $\mathrm{CSDP}^{+}$and fluconazole at the concentrations used.

\section{Conclusions}

Our experiments demonstrated that $\mathrm{CSDP}^{+}$at low concentrations alone or in combination with fluconazole was not toxic to HEK-293 cells. Moreover, this compound decreased the ability of $C$. albicans to adhere to HEK-293 cells. Fluorescence analysis of efflux activity showed that mammalian cells were able to protect themselves from low concentrations of $\mathrm{CSDP}^{+}$or fluconazole. The expression level of the efflux pump gene $A B C B 1$ in HEK-293 cells only slightly increased after the exposure of cells to the tested agents.

Treatment with $\mathrm{CSDP}^{+}$in combination with fluconazole resulted in a considerable overexpression of the MDR1 and MRR1 genes in C. albicans wt and clinical isolate strains. These findings suggest that the expression of MDR1 and MRR1 could be associated with fluconazole resistance related efflux, and our next step would be the analysis of fungicidal mechanism of $\mathrm{CSDP}^{+}$action in a wider range of clinical C. albicans and non-albicans isolates with a different degree of resistance.

Author Contributions: S.V. designed and performed biological experiments of this work and prepared the manuscript. L.B. and G.D. were responsible for the synthesis of the compound. G.D. was the leader of the chemical part of the project. R.D. participated in designing the experiments, revised the manuscript, and was the team leader. All authors have read and agreed to the published version of the manuscript.

Funding: This research was funded by the European Social Fund under "The Development of Competences of Scientists, other Researchers and Students through Practical Research Activities" measure (No. 09.3.-LMT-K-712-02-0200) under grant agreement with the Research Council of Lithuania (LMTLT). The authors appreciate the support by the Latvian group project NFI/R/2014/051.

Institutional Review Board Statement: Not applicable.

Informed Consent Statement: Not applicable.

Data Availability Statement: The data presented in this study are available on request from the corresponding author.

Acknowledgments: We thank Aurelija Žvirblienè (Center of Life Sciences, Vilnius University) for kindly providing HEK-293 cells and Laboratory of Microbiology, Republican Panevėžys Hospital (Lithuania), for providing the clinical isolate strain SV1.

Conflicts of Interest: The authors declare no conflict of interest.

\section{References}

1. White, T.C.; Holleman, S.; Dy, F.; Mirels, L.F.; Stevens, D.A. Resistance Mechanisms in Clinical Isolates of Candida albicans. Antimicrob. Agents Chemother. 2002, 46, 1704-1713. [CrossRef]

2. Teo, J.Q.; Lee, S.J.-Y.; Tan, A.-L.; Lim, R.S.-M.; Cai, Y.; Lim, T.-P.; Kwa, A.L.H. Molecular mechanisms of azole resistance in Candida bloodstream isolates. BMC Infect. Dis. 2019, 19, 63. [CrossRef]

3. Li, F.; Palecek, S.P. EAP1, a Candida albicans Gene Involved in Binding Human Epithelial Cells. Eukaryot. Cell 2003, 2, 1266-1273. [CrossRef]

4. Mitchell, A.P. Dimorphism and virulence in Candida albicans. Curr. Opin. Microbiol. 1998, 1, 687-692. [CrossRef]

5. Liu, H. Transcriptional control of dimorphism in Candida albicans. Curr. Opin. Microbiol. 2001, 4, 728-735. [CrossRef]

6. Vaitkienè, S.; Kuliešienė, N.; Sakalauskaitė, S.; Bekere, L.; Krasnova, L.; Vigante, B.; Duburs, G.; Daugelavičius, R. Antifungal activity of styrylpyridinium compounds against Candida albicans. Chem. Biol. Drug Des. 2020. [CrossRef] [PubMed]

7. Dubur, G.Y.; Dobretsov, G.E.; Deme, A.K.; Dubure, R.R.; Lapshin, E.N.; Spirin, M.M. Fluorescent probes based on styrylpyridinium derivatives: Optical properties and membrane binding. J. Biochem. Biophys. Methods 1984, 10, 123-134. [CrossRef]

8. Shiraishi, Y.; Inoue, T.; Hirai, T. Local Viscosity Analysis of Triblock Copolymer Micelle with Cyanine Dyes as a Fluorescent Probe. Langmuir 2010, 26, 17505-17512. [CrossRef] [PubMed]

9. Wyrzykiewicz, E.; Prukała, W.; Kedzia, B. Synthesis and antimicrobial properties of N-substituted derivatives of (E)-alpha-(or gamma)-azastilbenols. Farmaco 1994, 49, 127-131. [PubMed] 
10. Prasad, R.; Gaur, N.A.; Gaur, M.; Komath, S.S. Efflux Pumps in Drug Resistance of Candida. Infect. Disord. Drug Targets 2006, 6, 69-83. [CrossRef] [PubMed]

11. Franz, R.; Michel, S.; Morschhäuser, J. A fourth gene from the Candida albicans CDR family of ABC transporters. Gene 1998, 220, 91-98. [CrossRef]

12. Sanglard, D.; Kuchler, K.; Ischer, F.; Pagani, J.L.; Monod, M.; Bille, J. Mechanisms of resistance to azole antifungal agents in Candida albicans isolates from AIDS patients involve specific multidrug transporters. Antimicrob. Agents Chemother. 1995, 39, 2378-2386. [CrossRef] [PubMed]

13. Lohberger, A.; Coste, A.T.; Sanglard, D. Distinct Roles of Candida albicans Drug Resistance Transcription FactorsTAC1, MRR1, andUPC2in Virulence. Eukaryot. Cell 2013, 13, 127-142. [CrossRef] [PubMed]

14. Coste, A.T.; Crittin, J.; Bauser, C.; Rohde, B.; Sanglard, D. Functional Analysis of cis- and trans-Acting Elements of the Candida albicans CDR2 Promoter with a Novel Promoter Reporter System. Eukaryot. Cell 2009, 8, 1250-1267. [CrossRef]

15. Schubert, S.; Rogers, P.D.; Morschhäuser, J. Gain-of-Function Mutations in the Transcription Factor MRR1 Are Responsible for Overexpression of the MDR1 Efflux Pump in Fluconazole-Resistant Candida dubliniensis Strains. Antimicrob. Agents Chemother. 2008, 52, 4274-4280. [CrossRef]

16. Huang, R.; Vider, J.; Serganova, I.; Blasberg, R. ATP-Binding Cassette Transporters Modulate Both Coelenterazine- and DLuciferin-Based Bioluminescence Imaging. Mol. Imaging 2011, 10, 215-226. [CrossRef]

17. Fukazawa, Y.; Kagaya, K. Molecular bases of adhesion of Candida albicans. J. Med. Vet. Mycol. 1997, 35, 87-99. [CrossRef]

18. Sardi, J.C.; Duque, C.; Mariano, F.S.; Marques, M.; Hofling, J.F.; Goncalves, R.B. Adhesion and invasion of Candida albicans from periodontal pockets of patients with chronic periodontitis and diabetes to gingival human fibroblasts. Med. Mycol. 2012, 50, 43-49. [CrossRef]

19. Rodrigues, L.; Ramos, J.; Couto, I.; Amaral, L.; Viveiros, M. Ethidium bromide transport across Mycobacterium smegmatis cell-wall: Correlation with antibiotic resistance. BMC Microbiol. 2011, 11, 35. [CrossRef]

20. Spengler, G.; Molnár, J.; Viveiros, M.; Amaral, L. Thioridazine induces apoptosis of multidrug-resistant mouse lymphoma cells transfected with the human ABCB1 and inhibits the expression of P-glycoprotein. Anticancer. Res. 2011, 31, $4201-4205$.

21. Shukla, J.N.; Kalsi, M.; Sethi, A.; Narva, K.E.; Fishilevich, E.; Singh, S.; Mogilicherla, K.; Palli, S.R. Reduced stability and intracellular transport of dsRNA contribute to poor RNAi response in lepidopteran insects. RNA Biol. 2016, 13, 656-669. [CrossRef] [PubMed]

22. Blair, J.M.A.; Piddock, L.J.V. How to Measure Export via Bacterial Multidrug Resistance Efflux Pumps. mBio 2016, 7, e00840-16. [CrossRef] [PubMed]

23. Olmsted, J., 3rd; Kearns, D.R. Mechanism of ethidium bromide fluorescence enhancement on binding to nucleic acids. Biochemistry 1977, 16, 3647-3654. [CrossRef] [PubMed]

24. Niklas, J.; Melnyk, A.; Yuan, Y.; Heinzle, E. Selective permeabilization for the high-throughput measurement of compartmented enzyme activities in mammalian cells. Anal. Biochem. 2011, 416, 218-227. [CrossRef]

25. Dunkel, N.; Blaß, J.; Rogers, P.D.; Morschhäuser, J. Mutations in the multi-drug resistance regulator MRR1, followed by loss of heterozygosity, are the main cause of MDR1 overexpression in fluconazole-resistant Candida albicans strains. Mol. Microbiol. 2008, 69, 827-840. [CrossRef]

26. Lyons, C.N.; White, T.C. Transcriptional Analyses of Antifungal Drug Resistance in Candida albicans. Antimicrob. Agents Chemother. 2000, 44, 2296-2303. [CrossRef]

27. Chen, L.M.; Xu, Y.H.; Zhou, C.L.; Zhao, J.; Li, C.Y.; Wang, R. Overexpression of CDR1 and CDR2 genes plays an important role in fluconazole resistance in Candida albicans with G487T and T916C mutations. J. Int. Med. Res. 2010, 38, 536-545. [CrossRef]

28. Wang, J.; Yang, D.-H.; Yang, Y.; Wang, J.-Q.; Cai, C.-Y.; Lei, Z.-N.; Teng, Q.-X.; Wu, Z.-X.; Zhao, L.-G.; Chen, Z.-S. Overexpression of ABCB1 Transporter Confers Resistance to mTOR Inhibitor WYE-354 in Cancer Cells. Int. J. Mol. Sci. 2020, 21, 1387. [CrossRef] 